\title{
The human capital: education and the green economy
}

\author{
Polina Petrusha ${ }^{1, *}$, Daria Kozlova ${ }^{1}$, Kristina Ivanova ${ }^{1}$ \\ ${ }^{1}$ ITMO University, Institute of International Development and Partnership, 197101, Kronverksky pr., \\ 49, St. Petersburg, Russia
}

\begin{abstract}
According to the Russia's Innovative Development Strategy until 2020 (Strategy) [1], one of the main goals of innovative growth of the Russian Economy lays in the advanced studies in the fields of renewable energy and low-carbon economy, genome medicine, and implementation of new technologies in agriculture, the fields in which Russia still faces with sufficient technological backlog. In general, the Strategy and following National Science project [2] approved in 2018 is aimed at Russia's transition from one of the most energy- and carbon-intensive countries to a sustainable low-carbon economy. Russia needs to attract additional resources in human and knowledge capital in order to eliminate or decrease this technological backlog and to join international scientific community's efforts in the field of green economy. This paper studies how influencing one of two pillars of the Global Innovation Index (GII), knowledge and technology output pillar, by implementing innovations in Russian higher education affects Russian innovative infrastructure and provides technical and resource baseline in reaching main strategic indicators of innovative development in Russia. This paper proposes a framework for attracting and retaining human resources and creating knowledge capital for transition to a sustainable low-carbon economy on the basis of micro and meso level changes.
\end{abstract}

\section{Introduction}

According to CDP Climate Change Report, Russia belongs to the Top 10 carbon emitters and energy-intensive countries in the world [3]. Russian energy consumption per capita is $6,160.07 \mathrm{kWh}$ that is $13,2 \%$ more than average consumption per capita in EU countries [4]. One of the key factors for Russia's being energy-intensive type of economy lays in high level of technical abrasion and insufficient level of modernization of the Russian energy industry. These factors cause huge energy wastage and carbon emissions [5]. Among BRICS countries, Russia, due to its' considerable natural resources, still mostly relies on fossil fuel. So, Russian renewable sources of energy account only for about $16 \%$ of total electricity generation, mostly from hydro and geothermal power [6]. In comparison with China, which is the second world's energy consuming country, Russia's development in terms of green economy is practically insignificant. China has made a notable progress in implementing renewable technologies by cooperating with foreign partners interested in environmental protection

\footnotetext{
* Corresponding author: pgpetrusha@corp.ifmo.ru
} 
project. Russian strategy in transition to green economy is based on making and implementing own innovations and its results [1-2] are still far from being sufficient. Analysis of BRICS courtiers' progress in transition to green economy shows that except Russia, all four BICS countries are involved in search of the renewable energy consumption, as it significantly increases GDP per capita of BICS countries [7].

Russia's Innovative Development Strategy to 2020 shows the main challenges Russia meets due to its underrun of implementing energy-saving and green energy technologies:

- growing uncertainty in further prospects of Russian economy, traditionally focused on using natural resources;

- inability of modernization in key Russian innovation-driven industries (aviation and rocket science, shipbuilding, electronic engineering) without using energy saving, lowcarbon and green energy technologies;

- lack of technological reserve, human and knowledge capital in green and energy saving R\&D and fundamental studies that leads to limited ability for international scientific cooperation in that fields [1].

The last challenge might be considered as the main cause of Russia's backlog in implementing low-carbon technology, as, according to Romer (1986), investment of human capital and existing knowledge in R\&D is vital for technological breakthrough in general and implementing alternative technologies in particular [9].

The above studies indicate the strong nexus between higher education, deficit of human capital in R\&Ds related to green, low-carbon and energy saving technologies, innovations output and prospects of Russia's transition to low-carbon and energy efficient economy. The objective of the study is to examine the impact of implementing innovative methods in forming human capital in Russian Higher Education and Research institutions to main pillars of Russian innovative output.

This study indicates prerequisites for a successful story in the context of the Innovative Development Strategy to 2020 KPIs and targets in overcoming challenges and presents preliminary results on how Russian HEIs as innovation-related drivers permeate deficit of human capital deficit in the field of low-carbon and green studies and scientific results and provide knowelege and human capital resource base for transition Russia to low-carbon economy.

\section{Materials and methods}

Findings presented in this article were built on the analysis of metrics of Global Innovation Index (GII) [10], KPIs and metrics of innovation activity indicated in Innovative Development Strategy to 2020 and other metrics of innovation process in Russia obtained from different sources. These metrics were compared with data acquired in case study research within the international Open Doors Scholarship project. Using case study as a research methodology common in social and life sciences, according to Thomas [11], provides studies in these fields with exploratory or explanatory analysis instrumental cases based on an illustrative and descriptive approach.

The case study is primarily oriented toward a deeper understanding of the role

of tertiary education institutions and innovation activities in these institutions in the diffusion of innovations at Russian economical in general and key Russian innovation-driven industries in particular.

\section{Accessing Dynamics of Russian Innovations by Global. Innovation Index}


According to the Global Innovation Index (GII) that measures the ratio of innovation output to innovation resources (innovation input) or impact of innovation resources to economy, the progress in reaching key innovation indicators in Russia is not positive. Russian economy has moved down from the $43^{\text {th }}$ to the $47^{\text {th }}$ position in GII over the past three years. Compared to China, which rose from the $25^{\text {th }}$ in 2016 to the $17^{\text {th }}$ in 2018 , Russian innovation system shows every sign of negative trends.

In terms of innovation resources, situation in Russia seems quite positive. According to the R\&D magazine's Global R\&D Funding Forecast 2018, Russia is on the $8^{\text {th }}$ place for gross expenditures on R\&D (1,52\% of GDP in 2017 and in 2018 (forecast)) [4]. Other important resources, evaluated by GII (i.e. tertiary enrolment, total expenditures on education, market size of the country, number of researches and ease of starting a business) are also in global top-25 [10].

GII relays on Innovation Efficiency Ratio (IER), which shows how much innovation output Russia is getting for its inputs. IER is calculated as ratio of the Output Sub-Index (results of innovative activities within the economy) to the Input Sub-Index (elements of the national economy that enable innovative activities).

Input Sub-Index has four main pillars:

1. Institutions pillar that shows the institutional framework of a country (political stability, ease of starting business and regulatory environment).

2. Human capital \& research pillar that reflects education and research activity in a country.

3. Infrastructure pillar, consisting of three sub-pillars: (1) Information and communication technologies (ICTs), accessibility of population to IT and online technologies and (2) General infrastructure, reflecting average of electricity output in $\mathrm{kWh}$ per capita, and (3) Ecological sustainability indicating ecologically friendly communication, transport, and energy infrastructures.

4. Market sophistication pillar showing availability of credit access to the international market, competition, and market scale [13].

According to GII Report 2018 Russia's rank in Innovation Input Sub-Index is 43 (out of 128). Russian input to innovations is positive in terms of Human capital \& research pillar ( $22^{\text {nd }}$ rank), business sophistication ( $33^{\text {rd }}$ rank), trade, competition, $\&$ market scale $\left(13^{\text {th }}\right.$ rank) and ICT infrastructure (37 ${ }^{\text {th }}$ rank), but is quite negative in terms of ecological sustainability (95 ${ }^{\text {th }}$ rank) and general infrastructure (73 ${ }^{\text {rd }}$ rank), sub-pillars directly reflecting Russia's progress in green economy. Yet, in general Russia's position in innovation input rank ( $\left.43^{\text {rd }}\right)$ is higher than its general index $\left(47^{\text {th }}\right)$ [8].

The main obstacle lays in the field of innovation output ( $56^{\text {th }}$ rank), the efficiency of how innovation resources are utilized.

Innovation Output Sub-Index is mostly determined by the following parameters:

1. Number of patent applications filed by country residents both at the national patent office and at the international level through the PCT.

2. Citable documents' H-index and number of scientific \& technical articles.

3. Number of hi-tech manufacturers and exports.

4. Information and computer technology spending and exports [1].

Higher education institutions in Russia significantly and directly influence the first two parameters.

The first parameter, number of patent applications, according to Patent Cooperation Treaty (PCT) [14] in Russia is mostly formed by applications by state R\&D Establishments, National research institutes and other tertiary educational organizations. All these institutions are the part of or collaborated with higher education system. The second parameter, number of scientific and technical papers and other $\mathrm{H}$-index citable papers are also the product of scientific organizations or tertiary educational institutions. 
On the other hand, two sub-pillars (ecological sustainability and general infrastructure of innovation input index), crucially influencing low rate of Input Sub-index are also related to efficiency of Higher and Research institutions output - their R\&D products in the field of green and low-carbon energy and an further commercialization and implementation of these R\&Ds in energy and industrial sectors.

So, modernization of higher education institutions, aimed at commercialization of R\&Ds and boosting publication activity is likely to result in increase of the Innovation Output SubIndex, general increase of Innovation Efficiency Ratio of Russian Economy and, finally, in shaping and acceleration of human and knowledge capital.

\section{Analysis of Implementing Russia's Innovative Development Strategy to 2020 in Higher Education}

Reaching KPIs of the Strategy that are formulated for scientific and educational sector in Russian higher education institutions is mostly related to implementation of the Russian Academic Excellence Project (Project 5-100). The Project, which is aimed to assist in the process Russian higher education internationalization, creation of world-class intellectual products and development of an outstanding academic reputation by conducting breakthrough research, was launched in May 2013 in accordance with Presidential Decree [15]. Participants of this project are 21 leading Russian universities.

Analysis of strategic roadmaps of participating universities shows that strategic initiatives aimed to increasing of innovation output, carried out by universities in a framework of this project could be arranged by the following groups of activities:

- establishing international research centers;

- $\quad$ arranging university system of R\&D commercialization (business incubators, SIEs (small innovative enterprises, participating in hi-tech start-ups, university-industry technology-push pilot projects);

- reorganization of management and HRM management systems to stimulate publication and patents applications activity (KPIs for faculty and research staff in number of publications and patent applications);

- collaboration with the leading international universities;

- international recruitment of foreign researches and faculty [15].

These measures have resulted in a considerable increase of scientific publications of scientists affiliated with Russian universities. According to SCImago Journal \& Country Rank, the number of citable documents published in international scientific journals had increased from 56113 in 2014 to 80796 in 2017 (+44\%) and Russia had moved up from $15^{\text {th }}$ to $12^{\text {th }}$ position in the ranking [16].

Nonetheless, this result is still far from China ( $2^{\text {nd }}$ position $)$ and India ( $5^{\text {th }}$ position) [16]. The number of patent applications through PCT system had increased from 953 in 2014 to 1097 in $2016(+15 \%)$ [10] and Russia had moved up to $13^{\text {th }}$ rank, but comparing it with Chinese 50674 applications in 2016 and annual growth for 14\% [17], we may say that Russia faces serious challenges in this field.

Despite strategic initiatives of Project 5-100, extensive growth of the number of publications and patent applications is limited by the number of young scientists (who are, according to PCT, mostly active in international publication activity) involved in research projects and their publication capability. The limitation of the number of young scientists is mostly related to the situation, that in the most successful fields of research, like Information and Computer Technology (ICT), young specialists prefer to concentrate on corporate R\&D projects and publish at Habr (https://habr.com/), the biggest European collaborative blog for ICT specialists, not in academic journals. This platform provides them with more efficient, 
targeted and faster reach of their outcomes in their field than academic journals. Researchers involved in academic R\&D projects and aimed at publication of scientific papers are limited by publication capacity, which is usually limited to two citable articles at the most. In terms of creating human capital for R\&Ds, commercialization of R\&Ds and implementing results of R\&Ds in corporate sector in the field of green economy and low-carbon energy, Russia faces another problem - this field is rather unpopular for local students due to the long period of implementation of their findings in the industry and lack of international cooperation projects. This seems to be a vicious cycle: international cooperation scientific projects that can boost scientific careers and provide grants and incomes to the young scientists could not be launched because of lack of number of qualified staff, so local R\&D projects in green economy cannot provide sufficient results without enough staff and international cooperation, industrial leaders cannot benefit from commercialization of R\&D solutions in green economy and have special divisions to implement scientific results, so demand for specialists in green economy on the labor market is rather low and students do not see career prospects in that field.

\section{Recruitment of international talented researches for accelerating and increasing efficiency of human capital for transition to the green economy}

One of the possible solutions for creating human and knowledge capital for transition to green economy and general accelerating extensive growth of publication and patent activities could be intensifying international recruitment of talented students to Master Degree and $\mathrm{PhD}$ programs.

Applying international recruitment as an instrument of increasing innovation output and boosting R\&D projects is a promising approach. OECD report "Education at a Glance 2018" [18] highlights the following features of Master Degree students who are involved or are willing to be involved in programs of studying abroad:

- they are more likely to access more advanced educational programs;

- they are more likely to concentrate on academic, not corporate, results than local students, so they are more active in university's publication and projects activity;

- graduates at that level make a large contribution to research and development (R\&D) and innovation;

- graduates are more likely to get involved in or post-migration programs in host countries and proceed $R \& D$ activity in universities or $R \& D$ centers for 2-3 years after graduation in order to get better career opportunities;

- international students tend to mainly enroll in science, technology, engineering and mathematics (STEM) fields of study, fields with the highest impact on innovations output. About one-third of OECD mobile students at all tertiary levels are enrolled in STEM fields of study, with the following break-down: engineering, manufacturing and construction (17\%); natural sciences, mathematics and statistics $(10 \%)$; and information and communication technologies $(6 \%)$ [18].

Endeavor in international students' recruitment has been made by all universities participating in Project 5-100 since 2014 and every university has a target of increasing the share of international students enrolled to the University, but their efforts have been mostly targeted on internationalization of education and increasing of academic mobility. These efforts resulted in considerable (for $25 \%$ from 2015 to 2017) increase of number of students [18]. Although, this growth has been mainly noticed for bachelor programs that out of global trends in international mobility, as there are four times more international students at master's than bachelor's level in most of OECD countries [19]. 
Moreover, independent, asynchronous policy of international recruitment by each university resulted in increasing of competition for international students (especially from CIS area) between Russian universities and (sometimes) in targeting on number of foreign students rather than on their quality.

To provide significant impact on innovation output, recruiting Master Degree students needs modernization. It has to be upgraded to a systematic, concurrent and targeted campaign of talent search for the entire Russian tertiary education fulfilled by leading Russian universities.

One of the ways that the Russian government is trying to modernize international recruitment policy is the Open Doors: Russian Scholarship Project that the Ministry of Education and Science of the Russian Federation had launched with the Russian Association "Global Universities" in 2017. It's the first and the only online international competition in Russia for students wishing to earn a Master's degree in over 400 Russian universities without entrance exams. Applicants from any country, age and with any specialization were eligible to apply as long as they had a bachelor degree, scientific achievements and passed an online test. In 2017 competition covered four subject areas (physics, mathematics, computer science and economics). The other feature of the project is that competition is organized not by one or several separate universities, but by 21 leading Russian universities that are promoted in one campaign. This eliminates competition between universities in international talent search and creates synergic effect for promoting to potential students the full bunch of opportunities to be involved in innovation and R\&D in Russia.

The targeted social media advertisement campaign and a contextual online advertising campaign has reached over 12 million people and yielded 8,600 applicants from 160 countries, thus achieving the goal of providing a broad reach, selecting the best and making Russian higher education accessible. Most winners of competition (94 people from 20 countries from CIS, Pakistan, Bangladesh, Palestine) choose STEM specialization (computer science, physics and programming) and by November 2018 nearly $20 \%$ of the winners got involved in R\&D projects of Russian Universities they've been enrolled and $32 \%$ are starting or willing to start publication activity even in ICT field. So, even if the targets of the project in terms of boosting innovative activity are far from being reached, the trend seems to be quite positive.

In the second year of the project that started on October 2018, the number of subject areas extended to 10: Biology, Computer science, Mathematics, Business \& Management, Politics \& International Studies, Psychology, Physics, Philology \& Linguistics, Chemistry and Economics. Analysis of first applications shows that STEM fields of study are more popular than humanities and acquire $70 \%$ of applicants. This year attracted $23 \mathrm{~K}$ applicants and more that $20 \%$ of them applied to energy, physics, chemistry, biology and other majors related possible R\&D projects in Green economy.

\section{Results}

The preliminary results of implementing competition for those applying for Master degree programs highlight the following:

1. Efficiency in accelerating human capital in Russian science in general and in green and low-carbon economy research as its crucial field could be reached by recruiting both local and foreign young scientists to boost interest to that field and create international scientific teams.

2. Scholarship could be a mean of talents' transfer from less economically developed countries to Russian R\&D and innovation ecosystem with further social impact on economies of the students' home countries. 
3. Involvement of Master Degree students aimed at academic R\&D activities can add additional resources to academic R\&D system and create competition for local students who'll need to boost their publication activities and R\&Ds to keep up with foreign students.

4. The project has established a baseline for building a map of brand awareness of Russian universities in the international educational market that can be used for creating a roadmap for further modernization and increasing competitiveness of Russian higher education and creates the grounds for innovations ecosystem upgrade.

Modernization of higher educational institutions through strategic initiatives as well as intensifying international recruitment through an array of available mechanisms are significant steps towards general development of the innovations-based and transition to green, low carbon economy in Russia and related increase of Russia's rank in global innovation rankings.

\section{References}

1. http://static.government.ru/media/files/4qRZEpm161xctpb156a3ibUMjILtn9oA.pdf

2. http://www.econom22.ru/pnp/natsionalnye-proektyprogrammy $/ \% \mathrm{D} 0 \% 9 \mathrm{D} \% \mathrm{D} 0 \% \mathrm{~B} 0 \% \mathrm{D} 1 \% 83 \% \mathrm{D} 0 \% \mathrm{BA} \% \mathrm{D} 0 \% \mathrm{~B} 0 . \mathrm{pdf}$

3. https://www.lenovo.com/us/en/social_responsibility/CDP-Climate-Change-Report2017.pdf

4. https://www.worlddata.info/europe/russia/energy-consumption.php

5. T. Boden, G. Marland, R.J. Andres, Global, Regional, and National Fossil-Fuel CO2 Emissions, 1751 - 2014 (2017) doi:10.3334/CDIAC/00001_V2017

6. http://blueandgreentomorrow.com/features/brics-renewable-energy-and-sustainabilityin-emerging-economies

7. K. Zaman, A. Abdullah, A. Khan, M. Mohd Nasir, A. Hamzah, S. Rahim, Renewable and Sustainable Energy Reviews 56, 1263-1271 (2016)

8. http://www.wipo.int/edocs/pubdocs/en/wipo_pub_gii_2018.pdf

9. P.M. Romer, Journal of Political Economy 94(5), 1002-1037 (1986)

10. https://www.globalinnovationindex.org/gii-2017-report

11. G. Thomas, Qual. Inq. 17(6), 511-521 (2011)

12. http://www.wipo.int/edocs/pubdocs/en/wipo_pub_gii_2016-annex1.pdf

13. http://digital.rdmag.com/researchanddevelopment/2018_global_r_d_funding_forecast? $\mathrm{pg}=3 \#$ pg3

14. http://www.wipo.int/edocs/pubdocs/en/wipo_pub_901_2018.pdf

15. https://5top100.ru/en/about/more-about/

16. https://www.scimagojr.com/countryrank.php?year=2017

17. http://www.wipo.int/edocs/pubdocs/en/wipo_pub_901_2018.pdf

18. https://doi.org/10.1787/eag-2018-en

19. Education of Foreign Citizens in the Higher Educational Institutions of the Russian Federation: Statistical Collection (Ministry of Education and Science of The Russian Federation, Center for Sociological Research, Moscow, 2018) 